\title{
A Kúria gyakorlatából
}

\section{BERKES BÁLINT ${ }^{1}$}

A Kúria itélkező és nemperes tanácsai 2021. június 1-je és november 15-e között az Alaptörvény alapvető jogokat és kötelességeket szabályozó Szabadság és felelősség címü fejezetéhez kapcsolódóan több alapjog érvényesülését vizsgálták, így döntést hoztak a családi élet tiszteletben tartásához való jogot, a közérdekü adatok megismeréséhez való jogot, a gyülekezéshez való jogot, a véleménynyilvánítás és a sajtó szabadságát, a tulajdonhoz való jogot, a tisztességes hatósági és bírósági eljáráshoz való jogot, valamint a jogorvoslathoz való jogot érintö ügyekben.

Kulcsszavak: családi élet tiszteletben tartásához való jog, közérdekű adatok megismeréséhez való jog, gyülekezéshez való jog, a véleménynyilvánítás szabadsága, sajtószabadság, tulajdonhoz való jog, tisztességes hatósági és bírósági eljáráshoz való jog, jogorvoslathoz való jog

\section{Fundamental Rights Cases of the Curia of Hungary between 1 June and}

\section{November 2021}

Between 1 June and 15 November 2021, the adjudicating and non-litigious panels of the Curia of Hungary examined the implementation of the following fundamental rights issues: the right to have one's family life respected [Article VI, paragraph (1) of the Fundamental Law of Hungary], the right to access data of public interest [Article VI, paragraph (3) of the Fundamental Law of Hungary], the right to peaceful assembly [Article VIII, paragraph (1) of the Fundamental Law of Hungary], freedom of expression [Article IX, paragraph (1) of the Fundamental Law of Hungary], freedom of the press [Article IX, paragraph (2) of the Fundamental Law of Hungary], the right to property (Article XIII of the Fundamental Law of Hungary), the right to have one's affairs handled impartially, fairly and within a reasonable time by the authorities [Article XXIV, paragraph (1) of the Fundamental Law of Hungary], the right to a fair trial [Article XXVIII, paragraph (1) of the Fundamental Law of Hungary] and the right to a judicial remedy [Article XXVIII, paragraph (7) of the Fundamental Law of Hungary].

Keywords: fundamental rights issues, the Curia of Hungary

1 A Kúria Nemzetközi Főosztályának munkatársa, e-mail: berkesb@kuria.birosag.hu 
A Kúria eljáró tanácsai a vizsgált időszakban az Alaptörvényben biztosított alapvető jogokkal kapcsolatban számos ügyben vizsgálódtak és tettek fontos megállapításokat.

A családi élet tiszteletben tartásához való jogot [az Alaptörvény VI. cikkének (1) bekezdése] a Kúria egy idegenrendészeti üggyel kapcsolatos közigazgatási cselekmény felülvizsgálata iránti perben elemezte.

A Kúria az elsőfokú bíróság ítéletét hatályában fenntartó felülvizsgálati ítélete indokolásában megállapította, hogy a felperes fogadó családtagja ügyében született végleges, a tartózkodási engedélykérelmet elutasító döntés elleni bírósági kereset nem vezetett eredményre, és a felperes fogadó családtagja a Magyarországon történő tartózkodásra érvényes jogcímmel nem rendelkezett. Hozzáfüzte ugyanakkor, hogy a támadott határozat meghozatalát követően bekövetkezett tények, körülmények ugyan alapot adhatnak egy újabb kérelem előterjesztésére, annak megfelelően egy újabb közigazgatási eljárás lefolytatására és újabb határozat meghozatalára, de nem változtatnak azon az alapvetésen, amely szerint a bíróságnak azt kell megítélnie, hogy a közigazgatási tevékenység a megvalósításakor fennálló tények figyelembevételével sérti-e a keresetben megjelölt jogszabályi rendelkezéseket. Ebből következően az elsőfokú bíróság helytállóan jutott arra a következtetésre, hogy a perbeli határozat meghozatalakor a fogadó családtag nem rendelkezett érvényes tartózkodási jogcímmel, ezért a felperes tartózkodási célja nem nyert igazolást. A Kúria döntésének elvi tartalmaként rögzítette, hogy családi együttélés biztosítása céljából tartózkodási engedélyt az a harmadik országbeli állampolgár kaphat, aki Magyarországon történő tartózkodásra érvényes engedéllyel, jogcímmel rendelkező személy családtagja. Az eltartott kiskorú tartózkodási engedély iránti kérelme ügyében hozott döntés - hacsak az ügy körülményeiből más nem következik - osztja az eltartásáért felelős személy tartózkodási engedély iránti kérelmének sorsát akkor is, ha a hatóság külön eljárásban dönt. ${ }^{2}$

A közérdekủ adatok megismeréséhez való joggal [az Alaptörvény VI. cikkének (3) bekezdése] a Kúria egy minősített adat megismerése tárgyában hozott közigazgatási határozat felülvizsgálata iránti perben foglalkozott.

A Kúria az elsőfokú ítéletet hatályában fenntartó ítélete indokolásában rámutatott arra, hogy a Kúria ítélkezési gyakorlata egységes a minősített adatok megismerését illetően, már több döntésében kifejtette, hogy a megismerési engedély alapvetöen az egyént megillető önrendelkezési jog érvényesülésének eszköze, a megismerési engedély biztosítja az egyént megillető önrendelkezés alapjogának érvényesülését még abban az esetben is, ha az egyén adatai a minősített adatok körébe tartoznak. Minősített adatok esetében az információs önrendelkezési jog a minősített adat védelméről szóló 2009. évi CLV. törvény (Mavtv.) 11. \$ (2) bekezdésének keretei között azonban korlátozott. A felperes felülvizsgálati kérelme nyomán a Kúria hangsúlyoz-

2 A Kúria Kfv.IV.37.079/2021/7. számú ítélete. 
ta, hogy a korlátozás abszolút, és semmiféle kapcsolata nincs azzal, hogy a felperes az adatokat megismerve azokat nem hozná nyilvánosságra.

Egyetértett a Kúria azzal az elsőfokú bírósági állásponttal, hogy a Mavtv. szerinti minősített adatok esetében a szükségességi-arányossági teszt elvégzése nem eredményez diszkrecionális jogkörben meghozott közigazgatási határozatot. A Kúria nem csupán a minősített adatok esetében, de a közigazgatási jog más területén is megállapította, hogy a bizonyítékok értékelése nem eredményez a Közigazgatási perrendtartás szerint felülvizsgálandó közigazgatási döntést. A Kúria által hivatkozott 2/2015. (XI. 23.) KMK-vélemény alapján az a közigazgatási határozat nem minősül mérlegelési jogkörben hozott határozatnak, amelyben a határozathozatalhoz szükséges bizonyítékok értékelése alapján döntési lehetőségeket nem biztosító jogszabály alkalmazásával dönt a hatóság. A KMK-vélemény indokolása leszögezi azt is, hogy a bizonyítás értékelése a hatóság részéről egyfajta mérlegelés, azonban ez a típusú mérlegelés a bírósági felülvizsgálat szempontjából nem jelent mérlegelési jogkört, ha a jogszabály az adott ügyben döntési lehetőségeket vagy kereteket nem tartalmaz.

Osztotta a Kúria a felperesnek azt a megállapítását, hogy a Mavtv. alkalmazásában a megismerési engedély az egyént megillető információs önrendelkezési jog érvényesülésének eszköze. A megismerési engedély biztosítja az alapjog érvényesülését még abban az esetben is, ha az egyén adatai a minősített adatok körébe tartoznak. Minősített adatok esetében az információs önrendelkezési jog a Mavtv. 11. $\mathbb{S}(2)$ bekezdésének keretei között korlátozott. Mint ahogy arra az elsőfokú bíróság helytállóan utalt, vizsgálódása arra terjedhet ki, hogy az eljárás során maradéktalanul érvényesültek-e a formai és tartalmi követelmények, vagyis a korlátozásra kizárólag törvényben meghatározott eljárás eredményeként került-e sor, és azt, hogy a korlátozás szükséges-e, és a korlátozással elérni kívánt célhoz képest arányos-e.

A 29/2014. (IX. 30.) AB határozat megállapításaira hivatkozással a Kúria rögzítette, hogy a Mavtv. az alapelvi rendelkezések között, a 2 . $\$$ (1) bekezdésében rögzíti a szükségesség és arányosság elvét, amelynek értelmében a közérdekủ adat nyilvánosságához füződő jogot minősítéssel korlátozni csak az e törvényben meghatározott feltételek fennállása esetén, a védelemhez szükséges minősítési szinttel és a feltétlenül szükséges ideig lehet. Az adatok minősítésével történő nyilvánosságkorlátozás Magyarország érdekeinek védelmét és az állam nemzetközi kötelezettségvállalásainak teljesítését szolgálja. A minősítőnek a közérdekű vagy közérdekből nyilvános adat minősítése felőli döntés során a minősítéshez fűződő közérdek mellett a minősítendő adat nyilvánosságához füződő közérdeket is figyelembe kell venni, és csak akkor dönthet az adat minősítéséről, ha minősítéssel elérni kívánt cél arányban áll a minősített adat nyilvánosságához füződő érdekkel.

Helyesen állapította meg az elsőfokú bíróság, hogy amennyiben az adat megismerése a minősítés alapjául szolgáló közérdek sérelméhez vezetne, a hatóságnak nincs lehetősége mérlegelésre, meg kell tagadnia a megismerési engedély kiadását. Hangsúlyozta a Kúria, hogy a védendő közérdek többfajta módon testesülhet meg, klasszikus esete, amikor konkrét személyre vonatkozik, de valamikor magának az eljárásnak a techniká- 
ját, módszerét, irányultságát védi. Amikor a hatóság vagy a bíróság elvégzi a szükségesség és arányosság tesztjét, csak ezekre lehet figyelemmel, és nem vonhatja mérlegelési körébe a felperes keresetében szereplő személyi körülményeket. A döntésének indokolásában még arra sem tehet utalást, hogy ezek érintettek voltak vagy sem. Mindebből következően a határozat és ítélet indokolása sem lehet bővebb, mint a törvényszövegre történő utalás, annak megjelölése, hogy milyen védendő közérdek alapozza meg a megismerési engedélykérelem elutasítását, továbbá az adat nyilvánosságra hozatala, jogosulatlan megszerzése, módosítása vagy felhasználása, illetéktelen személy részére hozzáférhetővé, valamint az arra jogosult részére hozzáférhetetlenné tétele károsítja-e a minősítéssel védhető közérdeket.

A felülvizsgálati kérelemmel szemben a korlátozás tényéből nem következik a hatékony bírói jogvédelem követelményének sérelme. A minősített adatot tartalmazó iratokat a bíróság megismerheti, azokat összevetheti az alperesi hatósági határozatban foglaltakkal, a felperesi hivatkozásokkal, és a jogorvoslati rendből következően az elsőfokú bíróság ezen értékelésének jogszerűségét a Kúria vizsgálhatja. A jogalkotó biztosítja, hogy érvényesüljön a kontradiktórius eljárás, az megfeleljen a felperes által hivatkozott strasbourgi emberi jogi bírósági elvárásoknak is. Nemzetbiztonsági minősített adatok esetén a felperes által idézett strasbourgi bírósági döntésekből sem vezethető le más elvárás a hatékony bírói jogvédelemre nézve.

A Kúria megállapította, hogy az elsőfokú bíróság a releváns felperesi előadásokat megvizsgálta, azokra reagált, indokolási kötelezettségének eleget tett. A Kúria a felülvizsgálati eljárást a rendelkezésre álló teljes iratanyag - közte kiemelkedő jelentőséggel a Kúriára bekért megismerési engedélyt érintő irat - alapján folytatta le. A Kúria eljáró tanácsa zárt tanácsülésen a vitatott iratot teljes terjedelmében áttanulmányozta. El tudta végezni a szükségességi és arányossági tesztet, megállapíthatta, hogy a megismerési engedély megtagadásához kapcsolódó személyes kár mértéke nem tudja felülírni azon nemzeti minősítést, amellyel érintett adat megismerése a minősítés alapjául szolgáló közérdek sérelméhez vezetne. ${ }^{3}$

A gyülekezéshez való jog [az Alaptörvény VIII. cikkének (1) bekezdése] érvényesülését a Kúria egy gyülekezési ügyben indított perben vizsgálta.

A Kúria mint elsőfokú bíróság az alperesi rendőrkapitányság határozatát megsemmisítő ítéletének indokolásában kifejtette, hogy a 3/2013. (II. 14.) AB határozatban foglaltak értelmében az Alaptörvény VIII. cikkének (1) bekezdéséből fakadó alkotmányos követelmény, hogy a gyülekezési jogról szóló törvény szerinti bírósági felülvizsgálatnak van helye a rendőrségnek a rendezvény bejelentéséről hozott, hatáskör hiányát megállapító döntésével szemben, ezért a bíróság az alperes döntésének jogszerűségét és megalapozottságát érdemben vizsgálta. A gyülekezési jogról szóló 2018. évi LV. törvény (Gytv.) 2. $\mathbb{\$}$ (1) bekezdése értelmében e törvény alkalmazása során gyűlés a legalább két személy részvételével közügyben való véleménynyilvání-

3 A Kúria Kfv.I.37.468/2021/7. számú ítélete. 
tás céljából tartott nyilvános összejövetel. A Kúriának a Gytv. 2. $\$(1)$ bekezdésében foglalt rendelkezések alapján arról kellett döntenie, hogy a felperes által bejelentett rendezvény megfelel-e a gyülés fogalmának, a Gytv. hatálya alá tartozik-e.

A Gytv. 2. \$-ához füzött indokolás értelmében a törvény egyértelműsíti azokat a tartalmi kritériumokat, amelyekre figyelemmel a gyülekezési jog által védett magatartások a sokaságtól megkülönböztethetők. Ezért mondja ki, hogy a törvény a közügyben való véleménynyilvánítás céljából zajló nyilvános gyủléseket tekinti a hatálya alá tartozónak. Az Alkotmánybíróság a gyülekezési jog hatálya alá tartozó gyűlésekkel összefüggésben már egy korai, 1992-es határozatában megállapította, hogy „a gyülekezési jog szorosan kapcsolódik a véleménynyilvánítás szabadságához, mivel a gyűlések megszervezése, megtartása, illetve az azokon való részvétel ad lehetőséget a vélemény közös kialakítására". A cél ilyen meghatározása biztosítja azt, hogy a nem ilyen célú gyüléseket a jogalkalmazó ne tekintse gyülekezési jog által védettnek, és gátat vessen a joggal való visszaéléseknek, valamint az elhúzódó, nyilvánvalóan nem a közügyekben való véleménynyilvánításra, hanem zaklatásra irányuló gyűléseknek. A gyülekezés fogalmával összefüggésben fontos az is, hogy mit tekintünk a „közügynek való véleménynyilvánítás céljából tartott nyilvános összejövetel" fogalmában közügynek. Az Alkotmánybíróság 55/2001. (IX. 29.) AB határozata és a 75/2008. (V. 29.) AB határozata szerint minden olyan ügyet közügynek kell tekinteni, amely nem korlátozódik egyes magánjogi jogalanyok magánérdekeire, hanem a legszélesebb értelemben vett közállapotokkal, közérdekủ kérdésekkel kapcsolatos vita tárgya. A közügyekben való véleménynyilvánítás köre nem szorítkozik kizárólag a széles értelemben politikai kérdésekre, utóbbi ugyanis egyik fontos, de nem kizárólagos eleme a közügyeknek.

Az alperes a Gytv. 11. $\mathbb{S}(2)$ bekezdésében foglaltak alapján a felperessel mint a rendezvény bejelentőjével egyeztetett, döntését a személyes egyeztetésen elhangzottakra alapította, az egyeztetésen elhangzottakat a határozatában rögzítette. A felek az egyeztetésen elhangzottakat eltérően értelmezték. A felperes álláspontja értelmében a gyülekezés írásban bejelentett célja nem változott, a rendezvény célja a közös tiltakozás és véleménynyilvánítás a győri rozsdaövezetbe tervezett kulturális negyed megépítése ellen, azonban az egyetértő szimpatizánsok támogatásukat a helyszínen alárásukkal is kifejezhetik, a pulttal kitelepülés, az aláírásgyűjtés az érdeklődők tájékoztatását is magában foglalja. Ezzel szemben az alperes kizárólag az egyeztetésen elhangzottakat vette figyelembe, illetve értékelte, a rendezvény írásban bejelentett és egyértelmű céljától eltérve. A Kúria döntése meghozatalakor - a felek lényeges részben eltérő értelmezésére figyelemmel - kizárólag a rendezvény írásban bejelentett célját vette figyelembe.

A felperes által bejelentett rendezvény megfelel a Gytv. 2 . $\mathbb{S}(1)$ bekezdése szerinti gyűlés fogalmának, mert annak célja közügyben való véleménynyilvánítás. Konkrétan a perbeli politikai szerveződés helyi szervezetének tagjaival, aktivistáival, valamint a gyüléshez a helyszínen esetlegesen csatlakozókkal közösen tiltakozás és véleménynyilvánítás a győri rozsdaövezetbe tervezett kulturális negyed megépítése ellen. Egyébként az a körülmény, hogy az egyetértő szimpatizánsok a támogatásukat 
a helyszínen aláírásukkal is kifejezhetik, és az érdeklődők számára tájékoztatást is nyújtanak, a rendezvénynek a gyűlés fogalma alá tartozását, a megtartandó rendezvény fö céljának jogi megítélését nem befolyásolta.

A kifejtettekre figyelemmel az alperes a Gytv. 2. $\$(1)$ bekezdésében foglalt rendelkezések megsértésével utasította vissza - hatáskör hiányára hivatkozással - a felperes bejelentését, ezért a Kúria az alperes határozatát megsemmisítette, azonban mellőzte az alperes új eljárásra és új határozat hozatalára kötelezését, mert a tényállás szerint megtartani szándékozott rendezvényekkel kapcsolatos új hatósági döntés meghozatala - az időmúlásra tekintettel - okafogyottá vált. ${ }^{4}$

A véleménynyilvánítás szabadságának [az Alaptörvény IX. cikkének (1) bekezdése] kérdésköre a Kúria előtt két ügyben is felmerült.

Az első ügyben egy sajtó-helyreigazítási perben a Kúria felülvizsgálati ítéletével a jogerős ítéletet hatályon kívül helyezte, az elsőfokú bíróság ítéletét megváltoztatta, és a sajtó-helyreigazítást kérő felperes keresetét elutasította. A Kúria ítéletének indokolásában hangsúlyozta, hogy a Legfelsőbb Bíróság PK 12. számú állásfoglalásának II. és III. pontjai értelmében a kifogásolt sajtóközleményt a maga egészében kell vizsgálni. A kifogásolt közléseket nem formális megjelenésük, hanem valós tartalmuk szerint kell megítélni. A közlemény egymással összetartozó részeit összefüggésükben kell értékelni, és az értékelésnél tekintettel kell lenni a társadalmilag kialakult közfelfogásra. A jogosult személyének megítélése szempontjából közömbös részletek, pontatlanságok, lényegtelen tévedések nem adnak alapot helyreigazításra. Véleménynyilvánítás, értékelés, bírálat, valamint a társadalmi, gazdasági, politikai, tudományos vagy művészeti vita önmagában ugyancsak nem lehet helyreigazítás alapja.

A Kúria hivatkozott arra, hogy az Alkotmánybíróság számos esetben foglalkozott a szabad véleménynyilvánításhoz való jog tartalmával, terjedelmével, jogi védelmével és korlátaival. A 7/2014. (III. 7.) AB határozat indokolása rögzíti, hogy a szabad véleménynyilvánításhoz való jog kitüntetett helyet foglal el az Alaptörvény alapjogi rendjében. A szabad szólás lehetősége egyrészt nélkülözhetetlen az egyéni autonómia kiteljesítéséhez, hiszen a személyiség kibontakoztatása teljes mértékben elképzelhetetlen anélkül, hogy bárki szabadon, tartalmi kötöttségek nélkül közölhesse másokkal nézeteit. Másrészt a szólásszabadság a demokratikus, plurális társadalom és közvélemény fundamentuma. A sajtószabadság a szólásszabadság intézménye, a sajtó mindenekelőtt a véleménynyilvánításnak, a véleményformálásnak és a véleményalkotáshoz nélkülözhetetlen információszerzésnek az eszköze. A szólásszabadság kitüntetett szerepe azzal jár, hogy egyrészt csak kivételes jelleggel kell engednie a korlátozásra felhozott más jogokkal, illetve alkotmányos értékekkel szemben, másrészt a szabad véleménynyilvánítást korlátozó törvényeket megszorítóan kell értelmezni. A közügyekkel összefüggő vélemény kinyilvánításának szabadsága a szólás- és sajtószabadság legbensőbb védelmi köréhez tartozik. A közügyek megvitatása körében elhangzó

4 A Kúria K.VII.40.690/2021/3. számú ítélete. 
véleménynyilvánítás és a rá vonatkozó védelem fókuszában elsődlegesen nem a szólással érintett személyek státusza áll, hanem az, hogy a megszólaló valamely társadalmi, politikai kérdésben fejtette ki a nézeteit. A véleménynyilvánítás szabadsága az értékítéletet kifejező, az egyén személyes meggyőződését közlő megszólalásokra attól függetlenül kiterjed, hogy a vélemény értékes vagy értéktelen, helyes vagy helytelen, tiszteletre méltó vagy elvetendő. A tényállítást tartalmazó megnyilvánulások szintén részei a szólásszabadságnak. Egyrészt valamely tény közlése is kifejezhet személyes véleményt, másrészt tényközlések nélkül a véleményformálás is ellehetetlenülne. Ugyanakkor a szólás- és sajtószabadság határainak megvonásánál indokolt különbséget tenni az értékítéletek és a tényállítások védettsége között. Míg a vélemények esetében a hamisság bizonyítása értelmezhetetlen, addig a bizonyíthatóan hamis tények önmagukban nem állnak alkotmányos védelem alatt. A politikai véleménynyilvánítás fokozott védelme mind a közügyekben megfogalmazott értékítéletekre, mind pedig a közügyek körébe tartozó tényállításokra vonatkozik. A tények közlése tipikusan a vélemények alapja, ezért még az alkotmányos értékkel egyébként nem rendelkező, utóbb hamisnak bizonyult tények esetében is indokolt, hogy a jogi felelősségre vonás a felróhatóság és az esetleges joghátrányok mértékének meghatározása körében figyelembe vegyék a közéleti viták minél szabadabb folyásának érdekét.

A perbeli esetben a másodfokú bíróság helytállóan állapította meg, hogy a perbeli írás nem tekinthető bủnügyi tudósításnak, hiszen nem a feljelentés tartalmát vagy a nyomozás menetét ismerteti, és arra sem merült fel adat, hogy az ügyvédi iroda tagjaival szemben bármilyen büntetőeljárási cselekményt foganatosítottak volna. Az alperes felelősségét pedig nem zárja ki az, hogy csupán egy másik sajtószerv cikkére hivatkozott a megindult büntetőeljárást illetően.

A felülvizsgálati kérelmet előterjesztő alperes szerint a kifogásolt kitétel az „érdemben”, illetve az „alig” kifejezések relatív tartalmára is figyelemmel, egyértelműen véleménynyilvánításnak minősül, a szerző értékítéletét fejezik ki, amely sajtó-helyreigazítás tárgya nem lehet. A felperes szerint azonban a közlés burkoltan valótlan tényállítást fejezett ki, az olvasó számára azt az „üzenetet” hordozza, hogy több mint tíz év alatt jelentős összegű közpénzt kapott megbízási díjként, ennek fejében azonban ténylegesen nem, vagy csak alig dolgozott.

A Kúria az alperes álláspontjával értett egyet, amely szerint a vitatott kitétel vélemény, így e tekintetben érdemi bizonyításnak nincs helye. Az a közlés, hogy a felperes „érdemben alig dolgozott a városnak”, a felperes munkájának értékeléséről alkotott véleménynek minősül. A ténybeli alapot pedig, amelyen az újságíró következtetése alapul, a polgármester feljelentése alapján hủtlen kezelés gyanúja miatt megindult büntetőeljárás képezte. Az elsőfokú bíróság álláspontjával szemben önmagában az, hogy a felperes tényszerủen jelentős számú ügyben látta el az érintett önkormányzat, illetve annak szervei, tisztségviselői jogi képviseletét, még nem jelenti a kifogásolt közlés cáfolatát. A közlés ugyanis tartalma szerint nem az ellátott ügyek számszerủen meghatározható mennyiségére, hanem a képviselet ellátásának minősítésére vonatkozik, amely szerint a cikk szerzője a felperes tevékenységét nem tekintette „érdemi” 
munkának. A kifejtettek szerint a vélemény lehet helyes vagy helytelen, a szabad véleménynyilvánítás joga alapvetően a véleménynyilvánítás lehetőségét védi, függetlenül annak tartalmától. A kifejtett vélemény érték- és valóságtartalmát a bíróság nem vizsgálhatja. Miután az önkormányzat részéről a felperes megbízási díját kétséget kizáróan közpénzből fizették ki, a közpénzzel való gazdálkodás közügynek tekinthető. A közéleti kérdésben a vita, a véleménynyilvánítás lehetőségei az átlagosnál tágabbak, ezeket az alkotmányos korlátokat az alperes a jelen esetben nem lépte túl. Miután véleménynyilvánítás nem lehet sajtó-helyreigazítás alapja, a Kúria megállapította, hogy a jogerős ítélet jogszabálysértő módon kötelezte helyreigazításra az alperest. ${ }^{5}$

A második ügyben a Kúria szintén egy sajtó-helyreigazítási perben vizsgálódott, a jogerős ítéletet hatályában fenntartó ítélete indokolásában leszögezte, hogy az Alkotmánybíróság több esetben fogalmazta meg elvi jelentőséggel azt, hogy a nyilvános közlés megítélése során elsőként arról szükséges dönteni, hogy az adott közlés a közügyekben való megszólalást, közérdekủ vitában kifejtett álláspontot tükröz-e, vagyis a közügyek szabad vitatásával áll-e összefüggésben. Ennek megítéléséhez pedig elsődlegesen a közlés megjelenésének módját, körülményeit, a vélemény tárgyát, kontextusát szükséges figyelembe venni. Így a közlést érintően vizsgálni kell a médium típusát, a közlés apropóját adó eseményt, illetve az arra érkező reakciókat és az adott közlésnek ebben a folyamatban játszott szerepét. További szempontként szükséges értékelni a kijelentés tartalmát, stílusát, illetve a közlés aktualitását, illetve célját. Amennyiben e körülmények értékelésével az állapítható meg, hogy a közlés a közügyek szabad vitatását érinti, úgy a közlés automatikusan a véleménynyilvánítási szabadság nyújtotta magasabb szintủ oltalmat élvezi. Az ilyen közlés ugyanis a közhatalom és a közhatalmat gyakorlók ellenőrzésének, ellenőrizhetőségének egyik legfőbb garanciája, amely egy plurális alapokra épülő társadalom demokratikus és nyílt müködéséhez nélkülözhetetlen követelmény. Az Alkotmánybíróság gyakorlata kiemeli azt is, hogy a véleményszabadság nemcsak bizonyos felfogások vagy eszmék, hanem magának a véleménynyilvánításnak a lehetősége előtt nyit szabad utat. Ebből következik, hogy a közügyeket érintő értékítéletek szabad folyása biztosított, hiszen a tényállításokkal szemben az értékítéletek közös sajátossága, hogy igazságtartalmuk nem ellenőrizhető és nem igazolható. A véleménynyilvánítás szabadsága ugyanakkor nem nyújt védelmet az olyan öncélú, a közügyek vitatási körén kívül eső, így a magán- vagy családi élettel kapcsolatos közlésekkel szemben, amelyek célja a puszta megalázás vagy bántó és sértő kifejezések használata. A közhatalom, illetve a közhatalmat gyakorlók ellenőrzése és a közvélemény tájékoztatása, figyelmének felhívása érdekében a vélemények bizonyos fokú túlzást, provokációt is magukban foglalhatnak.

Az Alkotmánybíróság egy másik határozatában kifejtette, hogy a véleménynyilvánítás szabadsága az értékítéletet kifejező, az egyén személyes meggyőződését közlő megszólalásokra attól függetlenül kiterjed, hogy a vélemény értékes vagy értéktelen, helyes vagy helytelen, tiszteletre méltó vagy elvetendő. A tényállítást tartalmazó meg-

5 A Kúria Pfv.IV.20.502/2021/5. számú ítélete. 
nyilvánulások szintén részei a szólásszabadságnak. Egyrészt valamely tény közlése is kifejezhet személyes véleményt, másrészt tényközlések nélkül a véleményformálás is ellehetetlenülne. A szólás- és sajtószabadság határainak megvonásánál ugyanakkor indokolt különbséget tenni az értékítéletek és a tényállítások védettsége között. Míg a vélemények esetében a hamisság bizonyítása értelmezhetetlen, addig a bizonyíthatóan hamis tények önmagukban nem állnak alkotmányos védelem alatt. A politikai véleménynyilvánítás fokozott védelme mind a közügyekben megfogalmazott értékítéletekre, mind pedig a közügyek körébe tartozó tényállításokra vonatkozik. Egyfelől a demokratikus jogállam intézményeinek és a demokratikus közéletet hivatásszerűen alakító politikusoknak a szabad bírálata, működésük, tevékenységük kritikája a társadalom tagjainak, az állampolgároknak, valamint a sajtónak olyan alapvető joga, amely a demokrácia lényegi eleme. Másfelől a tények közlése tipikusan a vélemények alapja, ezért még az alkotmányos értékkel egyébként nem rendelkező, utóbb hamisnak bizonyult tények esetében is indokolt, hogy a jogi felelősségre vonás során a felróhatóság és az esetleges joghátrányok mértékének meghatározása körében figyelembe vegyék a közéleti viták minél szabadabb folyásának érdekét.

A jogerős ítélet jogszabálysértés nélkül állapította meg azt, hogy a perbeli írás kifogásolt kitételei a korábbi koncessziós társaság, illetve az új üzemeltető között létrejött megállapodásról szóló véleménynyilvánításnak, kritikának minősül, ez a megállapodás egyértelmủen közpénzek felhasználását érinti, miután közterületek használatával, hasznosításával kapcsolatos bevételek sorsát érinti. A vita lényege egyértelműen a közpénz kezelését, az azzal való gazdálkodást érintette, így az ezzel kapcsolatos álláspontok szabadon kifejthetők. Az elsődleges jogi érdek a közpénzekkel való gazdálkodás szabad megvitatásának lehetőségéhez füződik, nincs jelentősége annak, hogy a korábban létrejött és meghosszabbított koncessziós szerződést a perbeli cikk szerzője jogilag mennyiben értékelte helytállóan. Ugyancsak nincs jelentősége a vélemény esetleges politikai irányultságának sem. Kritizálható az a körülmény is, hogy a koncessziós szerződésben miért nem rendezték megfelelően a megszűnés időpontjára nézve az esetlegesen még be nem hajtott díjak behajtás utáni felosztásának módját, arányait. Ebben a közéleti vitában a perbeli tartalommal kifejtett álláspont, kritika nem lépi túl a közügyekben lehetséges szabad véleménynyilvánítás lehetséges kereteit, figyelemmel arra is, hogy ilyen esetekben a különböző érdekek összemérése esetén a szabad véleménynyilvánításhoz füződő érdek élvez elsőbbséget. ${ }^{6}$

A sajtó szabadságát [az Alaptörvény IX. cikkének (2) bekezdése] érintő megállapításokat a Kúria két sajtó-helyreigazítási perben tett.

Az első perben a Kúria mint felülvizsgálati bíróság a jogerős ítéletet hatályában fenntartó ítéletének indokolása szerint helytállóan hivatkozott az alperes a felülvizsgálati kérelmében arra, hogy az Alaptörvény IX. cikkének (2) és (3) bekezdése alapján a sajtó a sajtószabadság által védett alkotmányos küldetését teljesíti, ehhez

6 A Kúria Pfv.IV.20.685/2021/4. számú ítélete. 
kapcsolódóan joga van a megfelelő tájékoztatás biztosítására. A sajtónak ez a joga azonban nem érvényesül korlátlanul. A sajtószabadságról és a médiatartalmak alapvető szabályairól szóló 2010. évi CIV. törvény (Smtv.) 12. \$-a ugyanis a tájékoztatás tekintetében olyan „kereteket” határoz meg, amelyek betartása az érintett sajtószerv kötelessége. Ezek megsértését a bíróságoknak a 317/2020. (VI. 19.) AB határozatban adott iránymutatás, a PK 12. és a PK 14. számú állásfoglalások alapján kell megítélnie. Minden sajtóközleményt a maga egészében kell vizsgálni, azokat nem a formális megjelenésük, hanem a valós tartalmuk alapján kell „minősíteni”. Emellett figyelemmel kell lenni a közlemény belső összefüggéseire és a társadalmilag kialakult közfelfogásra is.

A Kúria megállapítása szerint a másodfokú bíróság a 3145/2018. (V. 7.) AB határozatban meghatározott szempontrendszer alapján helytállóan foglalt állást abban a kérdésben, hogy a sérelmezett közlések megítélése körében abból kell kiindulni, hogy a cikkről tudósító sajtótájékoztatót közszereplő tartotta részben közérdeklődésre is számot tartó kérdésben, illetve hogy a cikkben megjelölt hotel értékesítésének és az ahhoz kapcsolt osztaléknak nincs közpénzzel kapcsolatos érintettsége, így a közszférával összekapcsolható eleme. A felperes személye ugyanis önmagában ezt a kapcsolatot sem közvetlenül, sem közvetve nem teremtette meg. A Kúria nem értett egyet a jogerős ítéletnek azzal a megállapításával, hogy a felperes a híradással érintett körben azért minősül közéleti szereplőnek, mert a politikus a politikai és gazdasági élet összefonódásáról kifejtett bírálata során ismert szereplőként hivatkozott a felperesre.

A Kúria a felperes közszereplői „minősége” megítélése körében nem kívánt eltérni attól a korábbi gyakorlatától, hogy a felperes ugyan nem minősül közszereplőnek, személye azonban a miniszterelnök közeli hozzátartozójaként a gazdasági életben való részvétele, vagyonosodása, a közpénzt és közbeszerzést érdeklő ügyek kapcsán közérdeklődésre tarthat számot, ezért a felperes türési kötelezettségének határai - a közszereplőkhöz hasonló mértékben - az ilyen ügyekben tágabbak. Fokozott türési kötelezettsége azonban kimerül abban, hogy az őt érintő, közérdeklődésre számot tartó témákban a nyilvánosság előtt kérdéseket intézhetnek hozzá. A Kúria megállapítása szerint a felperes - a cikkben írt adásvétel és osztalékkifizetés közpénzzel kapcsolatos érintettségének hiánya miatt - a sérelmezett első és második közlés tekintetében sem minősült közéleti szereplőnek.

Az Alkotmánybíróság gyakorlata szerint a sajtó tevékenységét akkor nem lehet híresztelésként értékelni, ha a közéleti szereplők sajtótájékoztatóján a közügyek vitájának körében egymást érintően tett kijelentésekről hủen, saját értékelés nélkül tudósít, a közlések beazonosítható forrását egyértelműen megjelöli és a jóhírnevet esetleg sértő tényállításokkal érintett személy cáfolatának is helyet biztosít, vagy a válaszadás lehetőségét felkínálja. A Kúria ezt a „mércét” szem előtt tartva nem kívánt eltérni attól a gyakorlatától, hogy a sajtószerv a politikai párt sajtótájékoztatójáról történő tudósítás esetében akkor mentesül az elhangzott közlések miatti helyreigazítás köte- 
lezettsége alól, ha a tudósítás a forrás pontos megjelölésével, valósághűen adja vissza az elhangzottakat, továbbá teret ad az ellentétes álláspontnak is.?

A második perben a Kúria határozatának indokolásában megismételte, hogy az Alkotmánybíróság gyakorlata szerint a sajtó tevékenységét akkor nem lehet híresztelésként értékelni, ha a közéleti szereplők sajtótájékoztatóján a közügyek vitájának körében egymást érintően tett kijelentésekről hűen, saját értékelés nélkül tudósít, a közlések beazonosítható forrását egyértelműen megjelöli, és a jóhírnevet esetleg sértő tényállításokkal érintett személy cáfolatának is helyet biztosít. A Kúria ezt a "mércét” szem előtt tartva nem kívánt eltérni attól a gyakorlatától, hogy a sajtószerv a politikai párt sajtótájékoztatójáról történő tudósítás esetében akkor mentesül az elhangzott közlések miatti helyreigazítás kötelezettsége alól, ha a tudósítás a forrás pontos megjelölésével, valósághủen adja vissza az elhangzottakat, továbbá teret ad az ellentétes álláspontnak is. ${ }^{8}$

A tulajdonhoz való jog (az Alaptörvény XIII. cikke) kapcsán a Kúria egy erdőgazdálkodási ügy miatt indult perben vizsgálódott.

A Kúria mint felülvizsgálati bíróság az illetékes törvényszék ítéletét hatályában fenntartó ítélete indokolásában kifejtette, hogy a felperes azon hivatkozása, amely szerint az Alaptörvényben rögzített tulajdonhoz való joga kiterjed a tulajdonának kerítéssel történő védelmére is, alaptalan hivatkozás, tekintettel arra, hogy egyrészt a tulajdonhoz való jog nem korlátozhatatlan alapjog, az az erdei életközösségek mint kiemelt társadalmi érték megóvása érdekében korlátozható, amelyet épp a felperessel szemben érvényre juttatott igénybevétel törvényi szabályozása biztosít. Másrészt a tulajdonhoz való jog nem feltétlenül terjed ki a tulajdon kerítéssel történő megvédésére. Harmadrészt pedig az elsőfokú ítélet helyesen állapította meg, hogy e hivatkozásnak az ügyben relevanciája nem volt, mivel a perbeli esetben releváns tény az volt, hogy a felperes az erdő igénybevételéhez engedéllyel nem rendelkezett.

A perbeli erdő védelmi vagy közjóléti elsődleges rendeltetése körében az ítélet helyesen állapította meg, hogy az alperesi hatóság mulasztása nem tekinthető az ügy érdemére kiható eljárási jogszabálysértésnek, tekintettel arra, hogy a perbeli erdő elsődleges rendeltetése nem tartozik a határozathozatal szempontjából releváns körbe. Az, hogy az elsőfokú ítélet a hatósági eljárás során keletkezett iratokra utalva megállapította, hogy ezen adat egyebekben megállapítható volt az erdőrészletlapok, továbbá a közhiteles hatósági nyilvántartás alapján, nem jelenti azt, hogy a bíróság az alperesi hiányokat jogszabálysértő módon pótolta volna, ezen iratok ugyanis a hatósági eljárás részét képezték. ${ }^{9}$

7 A Kúria Pfv.IV.20.440/2021/5. számú ítélete.

8 A Kúria Pfv.IV.20.849/2021/4. számú ítélete.

9 A Kúria Kfv.II.37.153/2021/6. számú ítélete. 
A tisztességes hatósági eljáráshoz való jog [az Alaptörvény XXIV. cikkének (1) bekezdése] a Kúria előtt négy ügyben merült fel.

Az első ügyben, egy felsőoktatási pótfelvételi kapcsán indult közigazgatási jogvitában a Kúria felülvizsgálati ítéletének indokolásában kiemelte, hogy a tisztességes hatósági eljárás követelménye alapján a közigazgatási szerv eljárása során köteles megtartani és másokkal is megtartatni a jogszabályi rendelkezéseket. Az alapelvek az eljárás egészének minőségére vonatkoznak. Amint azt az Alkotmánybíróság a 6/1998. (III. 11.) AB határozatában kifejtette, a tisztességes eljárás olyan minőség, amelyet az eljárás egészének és körülményeinek figyelembevételével lehet megítélni. Ezért egyes részletek hiánya ellenére éppúgy, mint az összes részletszabály betartása dacára lehet az eljárás méltánytalan vagy igazságtalan, avagy nem tisztességes. A tisztességes hatósági eljáráshoz való jog számos részjogosítványt foglal magában; így a jogszerűség elvét is. Ennek megfelelően a hatóság a hatáskörét a jogszabályokban elöírt célok megvalósítása érdekében gyakorolhatja, a helyes jogértelmezésnél nemcsak a jogszabály betűjét, hanem annak célját, értelmét, lényegi tartalmát is figyelembe véve kell eljárnia. Sérti a tisztességes eljárás és a rendeltetésszerủ hatósági jogalkalmazás követelményét a formálisan jogszerủ döntés akkor, ha annak eredményeként az ügyfél nem élhet a jogszabályban meghatározott joggal annak ellenére, hogy arra egyébként - tisztességes eljárás mellett - jogosult lett volna.

A felsőoktatási felvételi eljárásban a jelentkező az érettségi bizonyítványa és a középiskolai bizonyítványa, illetve a felsőfokú végzettséget tanúsító oklevele vagy pedig mindkettő alapján kérheti a pontszámítás elvégzését. A pontszámításhoz szükséges dokumentumokat csatolni kell a jelentkezéshez. A jelentkezési kérelem adatait és az ahhoz csatolt dokumentumokat az alperes ellenőrzi, és hiányosság esetén felhívást bocsát ki azok pótlására. A felsőfokú végzettséggel rendelkező jelentkező esetében a jelentkezési kérelem csak akkor minősül hiányosnak, ha a jelentkező az érettségi bizonyítványa és a középiskolai bizonyítványa alapján is kéri a pontszámítás elvégzését. Mindebből az következik, hogy a felsőoktatásban szerzett oklevél feltöltési hiányossága nem minősíti a jelentkezési kérelmet hiányosnak, így emiatt nem kell hiánypótlási felhívást kibocsátani. A jogalkotó nyilvánvalóan nem akarta hátrányosan megkülönböztetni a felsőfokú végzettséggel rendelkező jelentkezőket oly módon, hogy míg az érettségi bizonyítvány és a középiskolai bizonyítvány alapján való pontszámítással jelentkezők esetében e dokumentumok hiányossága esetén hiánypótlási felhívással segíti a jelentkezőt a sikeres felvételben, addig azon jelentkezők esetében, akik a felsőoktatásban szerzett oklevél minősítése alapján kérik a pontszámítást, már nem biztosítja ugyanezt a támogatást. A jogalkotói cél feltehetően az volt erre a helyzetre, hogy hiányos feltöltés esetén a közigazgatási szerv a saját nyilvántartásából ellenőrizze, illetve átemelje a jelentkezési kérelem elbírálásához szükséges, hiányzó adatokat.

A jogszabályok nem cél nélküliek, azt kell feltételezni, hogy egy előírásnak meghatározott célja van. Értelmetlen, cél nélküli kötelezettséget jogszabály nem ír elő a jogalanyoknak. Ezért önmagában az, hogy a felsőoktatásban szerzett oklevél teljes 
egészében nincs feltöltve nem jelentheti azt, hogy az oklevél minősítése alapján ne lehetne pontot számítani. Sem a határozatból, sem az elsőfokú ítéletből nem állapítható meg, hogy mely jogszabályi rendelkezés alapján kellett volna a felperesnek a felsőfokú oklevelét teljes egészében feltöltenie, de az sem, hogy mely adat hiánya miatt nem tudta az alperes az ellenőrzést elvégezni, a felperes pontjait kiszámolni. A Kúria szerint az alkalmazandó jogszabályhelyeknek - a tisztességes hatósági eljárás és a rendeltetésszerü jogalkalmazás alapelvi rendelkezések szem előtt tartásával történő - értelmezéséből az következik, hogy a felperes esetében az alperesnek először is meg kellett volna állapítania, hogy a felperes által feltöltött dokumentumból hiányzike olyan adat, amely miatt a jelentkezés ellenőrzését nem tudja elvégezni. Hiányosság esetén vagy az általa müködtetett nyilvántartásból át kellett volna emelnie a szükséges adatot, vagy a felperest hiánypótlásra kellett volna felhívni, de legalább az észleltekről - a hiányok pótlására lehetőséget adva - tájékoztatást kellett volna adnia. ${ }^{10}$

A második ügyben, egy adóhatósági határozat bírósági felülvizsgálata során a Kúria ítéletének indokolásában rögzítette, hogy az Alaptörvény XXIV. cikkének (1) bekezdése szerint mindenkinek joga van ahhoz, hogy ügyeit a hatóságok részrehajlás nélkül, tisztességes módon és észszerủ határidőn belül intézzék. A hatóságok törvényben meghatározottak szerint kötelesek döntéseiket indokolni. Az Alkotmánybíróság joggyakorlata a hatóságok tisztességes eljárása és az Alaptörvény XXVIII. cikkének (1) bekezdése alapján a bírósági eljárásokra fogalmazza meg a fair, avagy kiegyensúlyozott bírósági eljáráshoz való jogot. E jog tartalmának kibontása körében az Alkotmánybíróság széles körű jogértelmezést végzett, rögzítve, hogy a tisztességes bírósági eljárás követelménye az eljárásjogi garanciák érvényesülését is felöleli, és egy olyan minőséget jelent, amelyet az eljárás egészének és körülményeinek figyelembevételével lehet csupán megítélni. A fair bírósági eljáráshoz való jog több részjogosítványból épül fel, abszolút, azaz korlátozhatatlan jog, egyes részjogosultságai más alapjogok vagy alaptörvényi értékek viszonylatában a szükségesség/arányosság kritériumrendszerében érvényesülnek. Jogállami keretek között a „tisztességes” karakter minden közhatalom erejével felruházott eljárással szemben követelmény. Ezért a sajátosságok figyelembevétele mellett, de a hatósági eljárásban is meg kell jelennie a fair eljárás követelményének. Mindezekből következően az Alaptörvény XIV. cikke önálló, az ügyintézés alapjogaként ismeri el a fair hatósági eljáráshoz való jogot. Az alapjogi jogvédelem kiterjed a hatóságok részrehajlás nélküli, tisztességes módon és észszerű határidőn belül ügyintézésére, a hatósági aktusok törvényben meghatározott indokolására, a közigazgatási jogkörben okozott kár megtérítésére. Mindezek előrebocsátása után a Kúria megítélése szerint a felperes által az eljárás tisztességtelenségére felhozott körülmények nem álltak fenn. ${ }^{11}$

A harmadik, fogyasztóvédelmi üggyel kapcsolatos közigazgatási jogvitában a Kúria ítéletének indokolásában hangsúlyozta, hogy az az alperesi határozat egészén végigvonuló érvelés, amely „fenntartja” a korábbi, a bíróság jogerős alapítéletével

10 A Kúria Kfv.III.37.298/2021/5. számú ítélete.

11 A Kúria Kfv.I.35.147/2021/12. számú ítélete. 
megsemmisített döntésében foglalt álláspontját, teszi ezt úgy, hogy konkrét jogszabályi előírás helyett „követendő példára” és jogszabállyal alá nem támasztott ellenőrizhetetlen joggyakorlatra hivatkozik, nem felel meg a megismételt eljárásra vonatkozó iránymutatásnak. A határozatnak tartalmaznia kell - egyebek mellett - bizonyítékokkal alátámasztottan azokat az egyértelmủen, világosan megfogalmazott indokokat is, amelyeken az érdemi döntés alapul. A közigazgatási határozatban az egyes megállapítások mellé kell társítani az azt megalapozó jogszabályi rendelkezéseket. Kizárólag az a határozat alkalmas érdemi felülvizsgálatra, amely megfelel az előzőekben említett követelményeknek. A hatósági eljárások tisztességes intézése nemcsak alapvető jog, hanem az Alaptörvény XXIV. cikkében megfogalmazott, a döntések indokolással való ellátásának törvényes követelményéből fakadóan alkotmányos kötelezettség is. Az indokolási kötelezettség szerepe a döntés jogszerűségének és azon keresztül a közigazgatás joghoz kötöttsége betartásának ellenőrizhetősége, ekként egyike a törvényes és tisztességes eljárás garanciáinak. ${ }^{12}$

A negyedik, halvédelmi ügyben hozott határozat mint közigazgatási cselekmény jogszerüségének vizsgálata során a Kúria határozatának indokolásában kifejtette, hogy a közigazgatási hatósági döntés indokolásának - egyebek mellett - ki kell terjednie a megállapított tényállásra, a bizonyítékokra, a mérlegelés és a döntés indokaira, valamint az azt megalapozó jogszabályhelyek megjelölésére is. Nem formális, hanem az indokolás lényegi tulajdonsága miatt minőségi követelmény, hogy az így elkészült indokolás rendelkezzen a szükséges meggyőző erővel, vagyis legyen alkalmas arra, hogy ne csak a hatósági eljárás résztvevőinek, hanem a jogorvoslati fórumoknak, de akár a külső szemlélőknek a döntés megalapozottságával kapcsolatos kételyét eloszlassa. A hatósági döntések indokolására ugyanis nem azért van szükség, mert azt a közigazgatási eljárási törvény előírta, hanem azért, mert az Alaptörvény XXIV. cikkében biztosított tisztességes hatósági eljáráshoz való jogból ez kényszerítően következik. Az Alaptörvény XXIV. cikkének megfelelő indokolás tehát nem formalista módon „kipipálja” az eljárási törvényben felsorolt elemeket, hanem koherensen és következetesen, belső ellentmondások nélkül, a teljeskörüen tisztázott történeti tényállás és törvényi tényállás megállapításait egymásnak megfeleltetve, és ebből megfelelő, illetve megfelelően kifejtett, zárt logikai rendszert képző következtetéseket von le. Természetesen ezeknek a mélysége szükségszerủen esetről esetre eltérő. ${ }^{13}$

A tisztességes bírósági eljáráshoz való joggal [az Alaptörvény XXVIII. cikkének (1) bekezdése] a Kúria két ügyben foglalkozott.

Az első ügyben, egy mezőgazdasági támogatás tárgyában hozott közigazgatási aktus bírósági felülvizsgálata során a Kúria határozatának indokolásában a felperesnek az Alaptörvény XXVIII. cikke (1) bekezdésében foglalt tisztességes bírósági eljáráshoz való joga szempontjából rámutatott arra, hogy az Alkotmánybíróság következetes gyakorlata szerint a bíróságok indokolási kötelezettségéből nem következik „a felek

12 A Kúria Kfv.IV.37.679/2021/7. számú ítélete.

13 A Kúria Kfv.IV.37.372/2021/10. számú ítélete. 
által felhozott minden észrevétel egyenként való megcáfolási kötelezettsége, különösen nem a szubjektív elvárásaikat is kielégítő mélységű érvrendszer bemutatása". Az indokolási kötelezettség mindössze azt az elvárást támasztja a bírósággal szemben, hogy a döntés indokolásának az ügy érdeme szempontjából releváns kérdésekre kell kiterjednie és nem minden egyes részletre. ${ }^{14}$

A második, agrártámogatási ügyben hozott közigazgatási határozat bírósági felülvizsgálata során a Kúria felülvizsgálati ítéletének indokolásában megismételte az első ügyben kifejtette álláspontját, újfent kiemelve, hogy a bírósági határozatok kapcsán megjelenő indokolási kötelezettség mindössze azt az elvárást támasztja a bírósággal szemben, hogy a döntés indokolásának az ügy érdeme szempontjából releváns kérdésekre kell kiterjednie és nem minden egyes részletre. ${ }^{15}$

A jogorvoslathoz való jog [az Alaptörvény XXVIII. cikkének (7) bekezdése] kapcsán a Kúria két ügyben tett fontos megállapításokat.

Az első ügyben egy adójogi tárgyú közigazgatási jogvitában járt el a Kúria mint másodfokú bíróság, és az általa hozott végzés indokolásában azt mondta ki, hogy az Alaptörvény XXVIII. cikkének (7) bekezdése szerint mindenkinek joga van ahhoz, hogy jogorvoslattal éljen az olyan bírósági, hatósági és más közigazgatási döntés ellen, amely a jogát vagy jogos érdekét sérti. A jogorvoslathoz való jog - az Alkotmánybíróság állandó gyakorlata szerint - a jogalkotótól azt követeli meg, hogy a hatóságok érdemi, ügydöntő határozatai tekintetében tegye lehetövé a valamely más szervhez vagy ugyanazon szervezeten belüli magasabb fórumhoz fordulás lehetôségét. Az Alkotmánybíróság szerint a jogorvoslat lényegi, immanens eleme a jogorvoslás lehetősége is, vagyis az, hogy a jogorvoslati jog nyújtotta jogvédelem hatékony legyen, vagyis képes legyen a döntés által okozott sérelem orvoslására. A fentiekből nem következik, hogy a jogorvoslatot elbíráló szervnek a kérelemnek minden körülmények között helyt kell adnia, az azonban alkotmányos kötelezettség, hogy az eljárási szabályok által meghatározott keretek között a jogorvoslati eljárást lefolytassák és a jogorvoslati kérelemben írtakat a jogszabályban foglaltak szerint érdemben megvizsgálják. ${ }^{16}$

A második ügyben a Kúria egy illetékügyben indult közigazgatási jogvita során hozott végzésének indokolásában kifejtette, hogy a hatékony bírói jogvédelemből fakadóan a jogorvoslathoz való jog megköveteli, hogy az ne csak formális, hanem méltányos, fair, tisztességes is legyen, azaz egy számszaki tévesztés, elírás ne legyen a bírói eljárásban is visszafordíthatatlan, az adózó a közigazgatási per keretei között is kérhesse az ilyen típusú hiba kijavítását, összhangban a Közigazgatási perrendtartás preambulumában is megjelenített szubjektív jogvédelmi céllal: a bíróságnak a közigazgatás jogsértő tevékenységével szemben kell védelmet nyújtania az alanyi jogaikban és jogos érdekeikben sértett érintetteknek. A jogvédelem biztosítása az esetek

14 A Kúria Kfv.IV.35.166/2021/5. számú ítélete.

15 A Kúria Kfv.IV.35.202/2021/6. számú ítélete.

16 A Kúria Kpkf.VI.40.257/2021/2. számú végzése. 
jelentős részében a jogorvoslathoz való jog érvényre juttatását is szolgálja ott, ahol rendes, a közigazgatási rendszeren belüli jogorvoslat nem vehető igénybe, illetve a jogorvoslat nem vezetett eredményre. Miként az elsőfokú bíróság ítéletében levezette, a felperes az általa elkövetett tévesztést semmilyen módon nem tudta orvosolni a jogorvoslati eljárásokban, a bejelentés módosítására nem volt lehetősége. Mindezek alapján a Kúria megállapította, hogy az elsőfokú bíróság a felülvizsgálati kérelemben megjelölt körben jogszabálysértő döntést hozott, ezért a jogerős ítéletet a támadott részében hatályon kívül helyezte, az elsőfokú bíróságot pedig új eljárásra és új határozat hozatalára utasította. ${ }^{17}$

17 A Kúria Kfv.V.35.079/2021/8. számú végzése. 